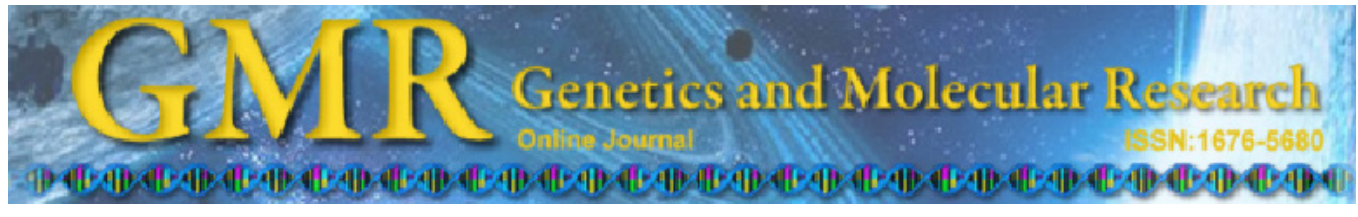

\title{
Prediction of health risk due to polycyclic aromatic hydrocarbons present in urban air in Rio de Janeiro, Brazil
}

\author{
C.R. Rainho ${ }^{1}$, A.M.A. Velho ${ }^{1}$, S.M. Corrêa ${ }^{2}$, J.L. Mazzei ${ }^{3}$, C.A.F. Aiub ${ }^{4}$ and \\ I. Felzenszwalb ${ }^{1}$
}

${ }^{1}$ Laboratório de Mutagênese Ambiental, Departamento de Biofísica e Biometria, Instituto de Biologia Roberto Alcântara Gomes, Universidade do Estado do Rio de Janeiro, Rio de Janeiro, RJ, Brasil ${ }^{2}$ Faculdade de Tecnologia, Departamento de Química Ambiental, Universidade do Estado do Rio de Janeiro, Resende, RJ, Brasil

3Plataforma de Métodos Analíticos, Farmanguinhos - Fundação Osvaldo Cruz, Rio de Janeiro, RJ, Brasil

${ }^{4}$ Laboratório de Genotoxicidade, Departamento de Genética e Biologia Molecular, Instituto Biomédico, Universidade Federal do Estado do Rio de Janeiro,

Rio de Janeiro, RJ, Brasil

Corresponding author: I. Felzenszwalb

E-mail: uerj.felzen@gmail.com

Genet. Mol. Res. 12 (3): 3992-4002 (2013)

Received July 4, 2012

Accepted November 10, 2012

Published February 28, 2013

DOI http://dx.doi.org/10.4238/2013.February.28.6

ABSTRACT. Risk assessment can provide a comprehensive estimate
of potential effects of contaminants under specific, well-defined, and
well-described circumstances, providing quantitative relationships
between exposure and effects to identify and to define areas of concern.
We investigated the mutagenic activity of particulate matter in air
samples collected from three sites in Rio de Janeiro city. Samples
were collected using a high-volume sampler at Avenida Brasil, at
Campus of Universidade do Estado do Rio de Janeiro, and at Rebouças
Tunnel. Six polycyclic aromatic hydrocarbons were quantified by gas
chromatography/mass spectrometry. Salmonella typhimurium TA98
and the derivative strains TA98/1.8-DNP, YG1021, and YG1024, 
commonly used in mutagenicity assays, were treated (10-50 $\mu \mathrm{g} / \mathrm{plate})$, with and without exogenous metabolization. The highest values for the polycyclic aromatic hydrocarbons were detected at Rebouças Tunnel. For chrysene, as an example, the concentration was nearly 200 times higher than that established by the US Environmental Protection Agency. Frequent traffic jams can place bus drivers who go through the Rebouças Tunnel at risk of exposure to up to $0.69 \mathrm{ng} / \mathrm{m}^{3}$ benzo(a) pyrene. Independent of exogenous metabolization, mutagenicity was detected in strains YG1021 and YG1024 at all the sites, suggesting nitro and amino derivatives of polycyclic aromatic hydrocarbons. Rebouças Tunnel air samples gave the highest values for rev/ $\mu \mathrm{g}$ and $\mathrm{rev} / \mathrm{m}^{3}$. This could be due to the fact that the long, enclosed passageway through a mountain restricts ventilation. The cancer risk estimate in this study was $10^{-3}$ for the benzo(a)pyrene, at the two sites, indicating a high risk.

Key words: Respirable particulate matter; PAHs; Risk assessment; Salmonella/microsome assay; Mutagenicity

\section{INTRODUCTION}

The risk assessment process involves the characterization of toxicities and estimation of possible adverse outcomes from specific chemical exposures (Environment Canada, 1997). The US Environmental Protection Agency (USEPA Draft Cancer Risk Assessment Guidelines, 1996) defines risk characterization as the step in the risk assessment process that integrates hazard identification, dose-response assessment, and exposure assessment, using a combination of qualitative and quantitative information.

The World Health Organization (WHO, 2005) considers air pollution to be an environmental exposure situation that can affect human health, where it is implicated in acute respiratory infections, cancer, and chronic respiratory and cardiovascular diseases. Studies around the world have consistently demonstrated that particulate matter (PM) with an aerodynamic diameter $<10 \mu \mathrm{m}$ (PM10) and, more recently, $<2.5 \mu \mathrm{m}$ (PM2.5), poses a significant threat to human health (Vinitketkumnuen et al., 2002) as it can penetrate deep into alveolar sacs in the lungs. It has been suggested that fine particles from automotive emissions are responsible for a $3 \%$ rise in mortality rate for every $10 \mu \mathrm{g} / \mathrm{m}^{3}$ increase, while fine coal combustion emissions account for only $1 \%$, and fine crystal aerosols have no discernible effect (Laden et al., 2000).

Urban airborne PM is a complex variable mixture containing many different chemical species (USEPA, 1996; Cassoni et al., 2004). Ambient air genotoxins can originate from fuel combustion (motor vehicle exhausts, central heating, and power generation), waste incineration, and industrial processes, and are also formed by atmospheric reactions (Claxton and Woodall Jr., 2007; Umbuzeiro et al., 2008). Studies on organic extracts of urban PM have proven their genotoxicity (Vinitketkumnuen et al., 2002; Cassoni et al., 2004), revealing the risk it poses to exposed populations. Generally, the mutagenicity of airborne combustion particles is primarily attributed to polycyclic aromatic hydrocarbons (PAHs), but recent reviews have demonstrated that these compounds are not the most predominant class of mutagens in airborne particulate matter, although they significantly contribute to mutagenicity. A wide 
range of aromatic compounds, such as nitroarenes, are found in ambient air and are present in emissions from direct sources or may be products of atmospheric reactions in the presence of $\mathrm{NO}_{2}$ and $\mathrm{NO}_{3}$ radicals (Coronas et al., 2009).

The objective of the present study was to make a risk assessment of the PM samples collected at three sites (Avenida Brasil, Rebouças Tunnel, and Campus of Universidade do Estado do Rio de Janeiro) in Rio de Janeiro between April and July 2010 for mutagenic activity using a Salmonella/microsome assay, as described by Kado et al. (1983).

\section{MATERIAL AND METHODS}

\section{Sampling sites}

The samples were collected at three sites in Rio de Janeiro: Avenida Brasil (site 1), Campus of Universidade do Estado do Rio de Janeiro (site 2), and Rebouças Tunnel (site 3 ) between April and July 2010. Site 1 has heavy traffic ( 250,000 vehicles/day) and is the city's biggest highway, spanning $58 \mathrm{~km}$ in length and crossing 27 neighborhoods. Site 2, with little traffic, is located in a residential area in the city's north zone. Site 3 has heavy traffic ( $\sim 190,000$ vehicles/ day). It connects the north and south zones of the city and is $2.8 \mathrm{~km}$ long.

\section{Sampling of airborne particulate matter and extraction of organic compounds}

Airborne PM2.5 samples were collected on fiberglass filters (E558 X 10IN, $254 \mathrm{~mm} \mathrm{x}$ $203 \mathrm{~mm}$ ) using a high-volume collector (Energética Indústria e Comércio Ltda., AVG MP 2.5, $1.13 \mathrm{~m}^{3} / \mathrm{min}$ ) for $24 \mathrm{~h}$ at Avenida Brasil and Universidade Federal do Rio de Janeiro, and $6 \mathrm{~h}$ in Rebouças Tunnel. Samples were collected each week from April to July 2010.

Half of each filter was extracted with dichloromethane (CASRN. 75-09-2, TediaBrazil, Brazil, purity $99.9 \%$ ) at $40^{\circ} \mathrm{C}$ by sonicating for three rounds of 10 min each (Vargas et al., 1998). The extracts were concentrated to $15 \mathrm{~mL}$ in a rotary evaporator and filtered on a Teflon membrane $(0.5 \mu \mathrm{m})$. The concentration of extractable organic matter $\left(\mathrm{EOM}\right.$, in $\left.\mu \mathrm{g} / \mathrm{m}^{3}\right)$ was calculated. Prior to bioassays, the organic extract was dried at $4{ }^{\circ} \mathrm{C}$ and resuspended in dimethyl sulfoxide (DMSO, CASRN. 67-68-5, Synth, Brazil, purity 99.9\%) (Vargas et al., 1998).

\section{Analysis of PAHs}

PAHs were quantified by gas chromatography/mass spectrometry (GC/MS). They were identified and quantified using a Varian system consisting of a GC (450-GC) with a split/ splitless injector $1177 \mathrm{~S} / \mathrm{SL}$ (kept at $300^{\circ} \mathrm{C}$ ) coupled to a mass spectrometer detector (MS 220). The ion trap $\left(250^{\circ} \mathrm{C}\right)$, manifold $\left(280^{\circ} \mathrm{C}\right)$, and transfer line $\left(280^{\circ} \mathrm{C}\right)$ were maintained at constant temperatures. PAHs were identified by mass similarity and by the retention time of the components in a commercial standard kit (Supelco, PAH610-S).

Quantification was based on five calibration points, which were constructed from each standard for all the target analytes, ranging from 10 to $250 \mathrm{pg} / \mu \mathrm{L}$. Injections $(2.0 \mu \mathrm{L})$ were splitless, with the split opened after $0.5 \mathrm{~min}$, and helium was used as the carrier gas. A VF$5 \mathrm{MS}$ column ( $30 \mathrm{~m} \times 0.25 \mathrm{~mm} \times 0.25 \mu \mathrm{m})$ was employed. The column and septum purge flows were set at 1.6 and $3 \mathrm{~mL} / \mathrm{min}$, respectively. The oven temperature program was as follows: 
$70^{\circ} \mathrm{C}$ for $4 \mathrm{~min}$ and $70-300^{\circ} \mathrm{C}$ at $10^{\circ} \mathrm{C} / \mathrm{min}$. These conditions were designed for the analysis of six PAHs: phenanthrene, fluoranthene, pyrene, benzo(a)anthracene, chrysene, and benzo(a) pyrene. The limits of quantification were determined from the minimum point in the calibration curves. Limits of detection were determined from PAH concentrations, which resulted in a signal-to-noise ratio of $3: 1$. The results were expressed in $\mathrm{ng} / \mathrm{m}^{3}$.

\section{Salmonella/microsome assay}

The organic extracts were assayed for mutagenicity using the microsuspension version (Kado et al., 1986) of the Salmonella/microsome assay (Maron and Ames, 1983). Salmonella typhimurium TA98 (frameshift strain) and the derivative strains YG1021 (nitroreductase-overproducing), TA98/1.8-DNP ${ }_{6}$ (O-acetyltransferase deficient) and YG1024 (O-acetyltransferase-overproducing) were used with and without metabolic activation (S9 mix fraction). Five concentrations of each sample $(10,20,30,40$, and $50 \mu \mathrm{g} /$ plate $)$ were tested in triplicate. The samples were pre-incubated for $90 \mathrm{~min}$. All assays were carried out under yellow light along with a negative control (DMSO solvent, $5 \mu \mathrm{L} /$ plate) and positive controls (4-nitroquinoline oxide, $0.5 \mu \mathrm{g} / \mathrm{plate}$, CASRN. 56-57-5 and 2-aminofluorene, $1 \mu \mathrm{g} / \mathrm{plate}$, CASRN. 153-78-6, Sigma Chemical Company, St. Louis, MO, USA). Plates were incubated in the dark at $37^{\circ} \mathrm{C}$ for $72 \mathrm{~h}$, after which time revertants were counted. The assay response for mutagenicity was considered positive when the number of revertant colonies in the test was at least twice the number of spontaneous revertants; the responses were expressed in rev/ $\mu \mathrm{g}$ and $\mathrm{rev} / \mathrm{m}^{3}$. In the cytotoxicity test, the solution containing the sample and the bacterial culture (100-200 cells) were plated on nutrient agar plates and incubated at $37^{\circ} \mathrm{C}$ for $24 \mathrm{~h}$, and the surviving colonies were counted (Vargas et al., 1998).

\section{Statistical analysis}

The mutagenic response was considered positive when the number of revertant colonies in the test was at least twice the number of spontaneous revertants and no cytotoxicity was detected (survival rates $>60 \%$ ). The significant responses were identified by statistical analysis (ANOVA, $\mathrm{P} \leq 0.05$ ) (Vargas et al., 1998).

\section{Risk assessment}

The risk assessment was calculated for each detected PAH by potency equivalency factors (PEFs) as described in Collins et al. (1998).

\section{RESULTS AND DISCUSSION}

\section{Airborne PM}

The PM2.5 concentration and EOM of the samples in $\mu \mathrm{g} / \mathrm{m}^{3}$ are shown in Table 1.

WHO (2005) has established guidelines for long-term and short-term PM2.5 concentrations: $10 \mu \mathrm{g} / \mathrm{m}^{3}$ (annual mean) and $25 \mu \mathrm{g} / \mathrm{m}^{3}$ (24-h mean). Most of our results were above the levels established by WHO (2005; Table 1). A previous study (Godoy et al., 2009) carried 
out near site 2 also detected low concentrations of PM2.5 $\left(18.10 \mu \mathrm{g} / \mathrm{m}^{3}\right)$, probably due to the fact that this area has low traffic flows and is far from any industry. A previous study done by Instituto Estadual do Ambiente (2009) to monitor PM10 in the metropolitan area of Rio de Janeiro showed a high annual average of this pollutant $\left(64 \mu \mathrm{g} / \mathrm{m}^{3}\right)$. WHO (2005) has established a guideline for long-term PM10 concentrations of $20 \mu \mathrm{g} / \mathrm{m}^{3}$ (annual mean). PM10 can only penetrate the upper respiratory tract, whereas PM2.5 can penetrate the lungs and cause various diseases (Claxton and Woodall Jr., 2007). It has been demonstrated that for each $10 \mu \mathrm{g} / \mathrm{m}^{3}$ increase in PM concentration, the risk of mortality from cardiopulmonary diseases increases $6 \%$, while the risk of mortality from lung cancer rises $8 \%$ (Ianistcki et al., 2009). Our results showed high concentrations of PM2.5 at sites 1 and 3. Most of the PM released into the atmosphere is from diesel-powered vehicles (Claxton and Woodall Jr., 2007). In Brazil, the fleet of gasoline-fueled vehicles rose by 8\% between 1996 and 2000, while for the same period there was a $60 \%$ increase in the number of diesel vehicles (SISAET, Sistema de Informações do Anuário Estatístico dos Transportes, 2011). The composition of diesel and gasoline has been changed (Braun et al., 2003) in a bid to reduce their pollutant emissions. Nevertheless, the PM concentration was found to be high at sites 1 and 3 - Avenida Brasil and Rebouças Tunnel where the traffic of diesel vehicles is heavy. The concentrations of PM2.5 detected at sites 1 and 3 are in agreement with other studies performed in urban areas: Santiago, Chile (33.00 $\mu \mathrm{g} /$ $\mathrm{m}^{3}$ ) (Seguel et al., 2009), Palermo, Italy $\left(34.20 \mu \mathrm{g} / \mathrm{m}^{3}\right.$ ) (Dongarrá et al., 2010), and Hong Kong $\left(68.60 \mu \mathrm{g} / \mathrm{m}^{3}\right)$ (Cheng et al., 2010).

Table 1. Collection sites, air volume, PM2.5 concentration, and extractable organic matter (EOM) of the
samples analyzed.
\begin{tabular}{llccc}
\hline Site & Month & Air volume $\left(\mathrm{m}^{3}\right) \pm$ SD & PM2.5 $\left(\mu \mathrm{g} / \mathrm{m}^{3}\right) \pm \mathrm{SD}$ & EOM $\left(\mu \mathrm{g} / \mathrm{m}^{3}\right)$ \\
\hline Avenida Brasil (1) & April & $1545 \pm 1$ & $40 \pm 12$ & 7.76 \\
& May & $1521 \pm 22$ & $60 \pm 22$ & 34.51 \\
& June & $1523 \pm 9$ & $34 \pm 21$ & 32.99 \\
UERJ (2) & July & $1518 \pm 1$ & $35 \pm 8$ & 4.93 \\
& April & $1618 \pm 87$ & $14 \pm 7$ & 6.02 \\
& May & $1518 \pm 65$ & $21 \pm 9$ & 8.16 \\
Rebouças Tunnel (3) & June & $1514 \pm 63$ & $35 \pm 28$ & 8.23 \\
\hline Pun & July & $1545 \pm 1$ & $36 \pm 15$ & 4.85 \\
\hline
\end{tabular}

$\mathrm{PM}=$ particulate matter; UERJ $=$ Universidade do Estado do Rio de Janeiro.

\section{Analysis of PAHs}

At site 1 in April, $0.07 \mathrm{ng} / \mathrm{m}^{3}$ chrysene was detected. In May, the following PAHs were detected: phenanthrene $\left(0.07 \mathrm{ng} / \mathrm{m}^{3}\right)$, fluoranthene $\left(0.13 \mathrm{ng} / \mathrm{m}^{3}\right)$, pyrene $\left(0.22 \mathrm{ng} / \mathrm{m}^{3}\right)$, benzo(a) anthracene $\left(0.15 \mathrm{ng} / \mathrm{m}^{3}\right)$, chrysene $\left(0.26 \mathrm{ng} / \mathrm{m}^{3}\right)$, and benzo(a)pyrene $\left(0.74 \mathrm{ng} / \mathrm{m}^{3}\right)$. In June, none of the PAHs evaluated were detected. In July, the following were detected: pyrene $(0.07$ $\left.\mathrm{ng} / \mathrm{m}^{3}\right)$, benzo(a)anthracene $\left(0.08 \mathrm{ng} / \mathrm{m}^{3}\right)$, chrysene $\left(0.17 \mathrm{ng} / \mathrm{m}^{3}\right)$, and benzo(a)pyrene $(0.19$ $\left.\mathrm{ng} / \mathrm{m}^{3}\right)$. None of the PAHs under study was detected at site 2 during the study period.

At site 3 , we detected phenanthrene $\left(0.23 \mathrm{ng} / \mathrm{m}^{3}\right)$, fluoranthene $\left(0.42 \mathrm{ng} / \mathrm{m}^{3}\right)$, pyrene $\left(0.53 \mathrm{ng} / \mathrm{m}^{3}\right)$, benzo(a)anthracene $\left(0.80 \mathrm{ng} / \mathrm{m}^{3}\right)$, chrysene $\left(1.78 \mathrm{ng} / \mathrm{m}^{3}\right)$, and benzo(a)pyrene $\left(1.65 \mathrm{ng} / \mathrm{m}^{3}\right)$. 
All PAHs evaluated in the present study are considered a priority in environmental monitoring, but only benzo(a)pyrene is believed to be a human carcinogen (group 1). Chrysene and benzo(a)anthracene are considered to be possibly carcinogenic to humans (group 2B), and the other PAHs evaluated in these study are classified as non-carcinogenic to humans (group 3) (IARC, 2011). By the estimated unit of risk, the chronic dose of benzo(a)pyrene for cancer is $1.10 \mathrm{ng} /$ $\mathrm{m}^{3}$, followed by $0.11 \mathrm{ng} / \mathrm{m}^{3}$ for benzo(a)anthracene, and $0.01 \mathrm{ng} / \mathrm{m}^{3}$ for chrysene (USEPA, 1996). Benzo(a)pyrene is the most carcinogenic, with the doses of benzo(a)anthracene and chrysene being calculated from benzo(a)pyrene. Benzo(a)pyrene has been identified in environmental studies as having the highest carcinogenic potential, with the capacity to form adducts and produce base substitutions and frameshifts (Fahl et al., 1981) in the DNA chain. Our study detected concentrations above the recommended levels estimated by USEPA, for chrysene (at site 1 - April, May, and July, and at site 3 - July), benzo(a)anthracene (at site 1 - May and at site 3 - July), and benzo(a)pyrene (at site 3 - July). The urban atmosphere in Rio de Janeiro is influenced by several factors, such as the uneven topography, the irregular occupation of space, the presence of open sea, and Guanabara Bay, which result in a complex regime for winds and irregular distribution and dispersion of pollution (Azevedo et al., 1999). A previous study performed from December 1998 to March 1999, close to site 1, reported similar values for benzo(a)pyrene (0.57-0.75 ng/ $\mathrm{m}^{3}$ ) (Fernandes et al., 2002). These results indicate that this pollutant is present during different periods of the year at this site. In another study in 1999 , at site $3,0.58 \mathrm{ng} / \mathrm{m}^{3}$ benzo(a)pyrene was determined, while we detected $1.65 \mathrm{ng} / \mathrm{m}^{3}$. This difference may be related to changes in the flow of vehicles, from about 7200 vehicles/day back then (Azevedo et al., 1999) to the present day level of 190,000 vehicles/day (CET-Rio - Companhia de Engenharia de Tráfego do Rio de Janeiro, 2011).

The existence of phenanthrene, fluoranthene, pyrene, benzo(a)anthracene, chrysene, and benzo(a)pyrene at sites 1 and 3 can be attributed to the heavy traffic and the absence of dispersion factors such as rainfall (especially at site 3). Moreover, the results found for sites 1 and 3 are in agreement with other studies performed in urban areas: Hong Kong (Zheng and Fang, 2000), Santiago (Kavouras et al., 1999) and São Paulo (Bourottea et al., 2005).

\section{Salmonella/microsome assay}

Tables 2 and 3 show the mutagenicity data for the organic extracts from airborne PM in $\mathrm{rev} / \mu \mathrm{g}$ and $\mathrm{rev} / \mathrm{m}^{3}$, respectively.

At site 1, positive responses were observed for TA98 both in the absence (April and May) and in the presence (July) of metabolic activation. A positive response was observed for TA98/1.8-DNP ${ }_{6}$ in July in the absence and in the presence of S9 mix. For YG1021, a positive response was observed in April, also in the absence and presence of S9 mix, while a positive response was observed in May, June, and July only in the presence of S9 mix. For YG1024, a positive response was observed in April in the presence of S9 mix, in May in the absence of S9 mix, and in July in the absence and presence of S9 mix.

At site 2, positive responses were observed for TA98 in the presence of metabolic activation in May, and in the absence and presence of metabolic activation in July. For TA98/1.8$\mathrm{DNP}_{6}$, a positive response was observed in the absence of metabolic activation in June and July. For YG1021 a positive response was observed in the presence of S9 mix in June and July. For YG1024, a positive response was observed in April in the absence of S9 mix and in July in the absence and presence of S9 mix. 
Table 2. Mutagenicity of airborne particulate matter organic extracts in rev/ $\mu \mathrm{g}$.

\begin{tabular}{|c|c|c|c|c|c|c|c|c|c|}
\hline \multirow[t]{2}{*}{ Site } & \multirow[t]{2}{*}{ Month } & \multicolumn{2}{|c|}{ TA98 } & \multicolumn{2}{|c|}{$\mathrm{TA} 98 / 1.8-\mathrm{DNP}_{6}$} & \multicolumn{2}{|c|}{ YG1021 } & \multicolumn{2}{|c|}{ YG1024 } \\
\hline & & $-\mathrm{S} 9$ & $+\mathrm{S} 9$ & -S9 & $+\mathrm{S} 9$ & $-\mathrm{S} 9$ & $+\mathrm{S} 9$ & $-\mathrm{S} 9$ & $+\mathrm{S} 9$ \\
\hline \multirow[t]{4}{*}{1} & April & $2.39 \pm 0.05$ & nd & nd & nd & $1.30 \pm 0.35$ & $1.18 \pm 0.14$ & nd & $3.35 \pm 1.48$ \\
\hline & May & $4.48 \pm 1.02$ & nd & nd & nd & nd & 1.86 & $1.40 \pm 0.20$ & nd \\
\hline & June & nd & nd & nd & nd & nd & $1.77 \pm 0.25$ & nd & nd \\
\hline & July & nd & $4.53 \pm 0.14$ & $6.50 \pm 0.57$ & $1.53 \pm 0.29$ & nd & 3.530 .08 & $5.60 \pm 1.69$ & $4.73 \pm 0.39$ \\
\hline \multirow[t]{4}{*}{2} & April & nd & nd & nd & nd & nd & nd & $0.90 \pm 0.14$ & nd \\
\hline & May & nd & $2.51 \pm 1.40$ & nd & nd & nd & nd & nd & nd \\
\hline & June & nd & nd & $1.61 \pm 0.05$ & nd & nd & $2.55 \pm 0.40$ & nd & nd \\
\hline & July & 2.85 & $3.28 \pm 0.35$ & $2.51 \pm 0.84$ & nd & nd & $2.05 \pm 0.25$ & $3.40 \pm 0.53$ & $1.59 \pm 0.51$ \\
\hline 3 & July & $3.43 \pm 0.67$ & $1.80 \pm 0.13$ & $1.93 \pm 0.63$ & nd & $3.80 \pm 0.57$ & $1.95 \pm 0.07$ & $7.50 \pm 4.38$ & $5.47 \pm 0.29$ \\
\hline
\end{tabular}

nd $=$ not detected. Negative control $=$ DMSO for the mutagenicity assay without S9 mix: TA98 $(35 \pm 5)$; TA98/1.8-DNP 6 (14 \pm 2$)$; YG1021 $(36 \pm 12)$; YG1024 $(21 \pm 3)$. For the mutagenicity assay with S9 mix: TA98 $(59 \pm 10)$; TA98/1.8-DNP $(22 \pm 2)$; YG1021 $(24 \pm 8)$; YG1024 $(44 \pm 2)$. Positive controls for the mutagenicity assay without S9 mix: $0.5 \mu \mathrm{g} /$ plate 4-nitroquinoline oxide for TA98 $(948 \pm 56)$; TA98/1.8-DNP 6 (1214 \pm 119$)$; YG1021 (953 \pm 62$)$; YG1024 (1154 \pm 97). For the mutagenicity assay with S9 mix: $1 \mu \mathrm{g} / \mathrm{plate}$ 2-aminofluorene for TA98 (184 \pm 15$)$; TA98/1.8-DNP 6 (246 \pm 47$)$; YG1021 (1216 \pm 104$)$; YG1024 (235 \pm 70$)$.

At site 3, positive responses were observed for TA98 in the absence and presence of metabolic activation. For TA98/1.8-DNP ${ }_{6}$ a positive response was observed only in the absence of S9 mix. For YG1021 and YG1024, positive responses were observed in the absence and presence of metabolic activation (Table 3 ).

The mutagenicity observed in the presence of metabolic activation may be associated with the presence of promutagens, such as PAHs. Benzo(a)pyrene was present in the samples from site 1 (May and July) and site 3 (July). The positive response for TA98 in the presence of S9 mix might have been related to this PAH at sites 1 and 3 in July. It is known that benzo(a)pyrene can induce frameshift mutations in DNA at a concentration of $0.5 \mu \mathrm{g} /$ plate for TA98 in the presence of metabolic activation (Aouadene et al., 2008). In our results, we detected benzo(a)pyrene at site $1(0.05 \mu \mathrm{g} /$ plate $)$ in July, and at site $3(0.61 \mu \mathrm{g} / \mathrm{plate})$ also in July. Although we detected the presence of benzo(a)pyrene in May at site 1, no mutagenic response related to this PAH was observed.

The positive response observed at the three sites for the O-acetyltransferase strains (TA98/1.8-DNP ${ }_{6}$ and YG1024) suggests the presence of amino compounds. The positive response observed at the three sites for the nitroreductase-overproducing strain (YG1021) could be related to the presence of nitro derivatives of PAHs.

At sites 1 and 2 (outside), the highest values for $\mathrm{rev} / \mu \mathrm{g}$ and $\mathrm{rev} / \mathrm{m}^{3}$ for different strains (Tables 3 and 4, respectively) were observed in July (winter). In Rio de Janeiro, there is normally little rainfall in winter. The lack of rain in this season favors the accumulation of these pollutants in the atmosphere. A previous study evaluating the mutagenicity of PM10 near site 2 in the winter of 1984 showed a positive response for TA98 in the presence of S9 mix (2.60 $\mathrm{rev} / \mu \mathrm{g}$ and $5.98 \mathrm{rev} / \mathrm{m}^{3}$ ) (Miguel et al., 1990). At this site in the same season, we found higher

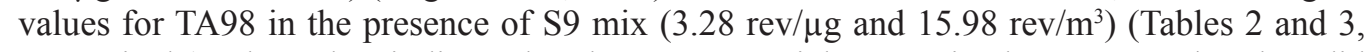
respectively). These data indicate that the PM2.5 particles contained more PAHs $/ \mu \mathrm{g}$ than did the PM10 particles (Claxton and Woodall Jr., 2007).

Site 3 (inside) exhibited the highest rev/ $\mu \mathrm{g}$ and $\mathrm{rev} / \mathrm{m}^{3}$ values of the three sites. This finding might have been related to the fact that the long enclosed tunnel running through the mountain has limited ventilation and high traffic volume. 
Table 3. Mutagenicity of airborne particulate matter organic extracts in rev/ $\mathrm{m}^{3}$.

\begin{tabular}{|c|c|c|c|c|c|c|c|c|c|}
\hline \multirow[t]{2}{*}{ Site } & \multirow[t]{2}{*}{ Month } & \multicolumn{2}{|c|}{ TA98 } & \multicolumn{2}{|c|}{ TA98/1.8-DNP ${ }_{6}$} & \multicolumn{2}{|c|}{ YG1021 } & \multicolumn{2}{|c|}{ YG1024 } \\
\hline & & $-\mathrm{S} 9$ & $+\mathrm{S} 9$ & $-\mathrm{S} 9$ & $+\mathrm{S} 9$ & $-\mathrm{S} 9$ & +S9 & -S9 & +S9 \\
\hline \multirow[t]{4}{*}{1} & April & $18.50 \pm 0.38$ & nd & nd & nd & $10.08 \pm 2.74$ & $9.15 \pm 1.09$ & nd & $26.00 \pm 11.52$ \\
\hline & May & $154.60 \pm 35.14$ & nd & nd & nd & nd & 64.18 & $48.50 \pm 6.36$ & nd \\
\hline & June & nd & nd & nd & nd & nd & $58.49 \pm 8.25$ & nd & nd \\
\hline & July & nd & $22.32 \pm 0.70$ & $32.04 \pm 2.78$ & $7.52 \pm 1.42$ & nd & $17.41 \pm 0.37$ & $27.60 \pm 8.36$ & $23.29 \pm 1.92$ \\
\hline \multirow[t]{4}{*}{2} & April & nd & nd & nd & nd & nd & nd & $5.41 \pm 0.85$ & nd \\
\hline & May & nd & $20.48 \pm 11.42$ & nd & nd & nd & nd & nd & nd \\
\hline & June & nd & nd & $13.24 \pm 0.45$ & nd & nd & $19.33 \pm 2.32$ & nd & nd \\
\hline & July & 13.82 & $15.90 \pm 1.71$ & $12.20 \pm 4.07$ & nd & nd & $9.94 \pm 1.20$ & $16.51 \pm 2.61$ & $7.73 \pm 2.50$ \\
\hline 3 & July & $62.41 \pm 12.10$ & $32.72 \pm 2.40$ & $35.14 \pm 11.43$ & nd & $69.08 \pm 10.28$ & $35.45 \pm 1.28$ & $136.34 \pm 79.70$ & $99.50 \pm 5.22$ \\
\hline
\end{tabular}

$\mathrm{nd}=$ not detected. Negative control = DMSO for the mutagenicity assay without S9 mix: TA98 (35 \pm 5$)$; TA98/1.8$\mathrm{DNP}_{6}(14 \pm 2)$; YG1021 (36 \pm 12$)$; YG1024 $(21 \pm 3)$. For the mutagenicity assay with S9 mix: TA98 (59 \pm 10$)$; TA98/1.8-DNP 6 (22 \pm 2$)$; YG1021 (24 \pm 8$)$; YG1024 $(44 \pm 2)$. Positive controls for the mutagenicity assay without S9 mix: $0.5 \mu \mathrm{g} /$ plate 4-nitroquinoline oxide for TA98 (948 \pm 56$)$; TA98/1.8-DNP 6 (1214 \pm 119$)$; YG1021 $(953 \pm$ 62); YG1024 (1154 \pm 97). For the mutagenicity assay with S9 mix: $1 \mu \mathrm{g} /$ plate 2-aminofluorene for TA98 $(184 \pm$ 15); TA98/1.8-DNP 6 (246 \pm 47); YG1021 (1216 \pm 104$) ;$ YG1024 (235 \pm 70$)$.

\begin{tabular}{|c|c|c|c|}
\hline Sites & PAHs & PEF & Individual cancer risk \\
\hline \multicolumn{4}{|l|}{ Avenida Brasil (1) } \\
\hline April & Chrysene & 0.01 & $7.710^{-7}$ \\
\hline \multirow[t]{6}{*}{ May } & Phenanthrene & 0.001 & $7.710^{-8}$ \\
\hline & Fluoranthene & 0.001 & $1.410^{-7}$ \\
\hline & Pyrene & 0.001 & $2.410^{-7}$ \\
\hline & Benzo(a)anthracene & 0.1 & $1.710^{-5}$ \\
\hline & Chrysene & 0.01 & $2.910^{-6}$ \\
\hline & Benzo(a)pyrene & 1 & $0.810^{-3}$ \\
\hline \multirow[t]{4}{*}{ July } & Pyrene & 0.001 & $7.710^{-8}$ \\
\hline & Benzo(a)anthracene & 0.1 & $8.810^{-6}$ \\
\hline & Chrysene & 0.01 & $1.910^{-6}$ \\
\hline & Benzo(a)pyrene & 1 & $0.210^{-3}$ \\
\hline \multirow[t]{6}{*}{ Rebouças Tunnel (3) } & Phenanthrene & 0.001 & $2.510^{-7}$ \\
\hline & Fluoranthene & 0.001 & $4.610^{-7}$ \\
\hline & Pyrene & 0.001 & $5.810^{-7}$ \\
\hline & Benzo(a)anthracene & 0.1 & $8.810^{-5}$ \\
\hline & Chrysene & 0.01 & $1.910^{-5}$ \\
\hline & Benzo(a)pyrene & 1 & $1.810^{-3}$ \\
\hline
\end{tabular}

The detailed derivation of each potency equivalency factors (PEF) can be found in OEHHA (1994).

\section{Risk assessment}

Table 4 shows the risk assessment. In the estimate of individual risk of cancer, values on the order of $10^{-8}$ to $10^{-3}$ were detected at site 1 in April, May and July. At site 3, observed values were on the order of $10^{-7}$ to $10^{-3}$ for the PAHs listed in Table 4.

The evaluation of health effects and quantitative risk could be carried out for every $\mathrm{PAH}$, where estimating the risk of cancer using PEFs is usually measured relative to benzo(a) pyrene, since it is the only PAH for which a complete quantitative risk assessment has been done (Collins et al., 1991; OEHHA, 1994). The use of PEFs for estimating risk from exposure to PAHs is an improvement for those PAHs for which there are reliable collection and measurement techniques. However, there are a large number of PAHs for which PEFs have not yet 
been determined and/or for which measurement techniques are unavailable. PEFs are primarily based on chronic internal dosing experiments and skin-painting studies (Collins et al., 1998). Explanations of the derivation of each PEF, the type of data used for the derivation, and the relevant references were presented in a technical report that underwent public and scientific peer review (OEHHA, 1994); the derivations are detailed in that report (Collins et al., 1998).

In this study, the highest risks were detected for benzo(a)anthracene and for benzo(a)pyrene in May at site 1, and for benzo(a)anthracene, chrysene and benzo(a)pyrene at site 3. According to Collins et al. (1998), a risk of about $10^{-5}$ could lead to notification of the public. These data reflect the risk to which people using these routes are exposed daily. In general, bus drivers who work at sites 1 and 3 spend, respectively, $4 \mathrm{~h}$ and $10 \mathrm{~min}$ daily on these roads. Considering these data and the PAH concentrations detected, we can extrapolate how much these workers are at risk of PAH exposure. Traffic jams are frequent at site 3, lasting up to $2 \mathrm{~h}$ (http://www.jb.com.br/rio/noticias) and subjecting bus drivers to a risk of exposure of up to $0.69 \mathrm{ng} / \mathrm{m}^{3}$ benzo(a)pyrene. This concentration is above the USEPA limit, and several studies have demonstrated an increase in DNA adducts at this level (Topinka et al., 1997; Lewtas et al., 1997; Kyrtopoulos et al., 2001).

In conclusion, nitro and amino derivatives of PAHs contributed to the mutagenicity detected for PM2.5. Furthermore, the population that uses routes 1 and 3, especially the bus drivers, are more exposed to cancer risk. This study reinforces the importance of using cleaner fuels and having better indoor ventilation. These measures could result in a reduction in diseases related to air pollution caused by PM2.5, and a consequent improvement in quality of life.

\section{ACKNOWLEDGMENTS}

Research supported by Fundação Carlos Chagas Filho de Amparo à Pesquisa do Estado do Rio de Janeiro (FAPERJ, \#23/2008), Coordenação de Aperfeiçoamento de Pessoal de Nível Superior (CAPES), and Conselho Nacional de Desenvolvimento Científico e Tecnológico $(\mathrm{CNPq})$. We are grateful to the Rio de Janeiro city Departments of Education and Transportation for their partnership in this study.

\section{REFERENCES}

Aouadene A, Di Giorgio C, Sarrazin L, Moreau X, et al. (2008). Evaluation of the genotoxicity of river sediments from industrialized and unaffected areas using a battery of short-term bioassays. Environ. Mol. Mutagen. 49: 283-299.

Azevedo DA, Moreira LS and Siqueira DS (1999). Composition of extractable organic matter in aerosols form urban areas of Rio de Janeiro city, Brazil. Atmos. Environ. 33: 4987-5001.

Bourottea C, Fortic MC, Taniguchid S, Bícego MC, et al. (2005). A wintertime study of PAHs in fine and coarse aerosols in São Paulo city, Brazil. Atmos. Environ. 39: 3799-3811.

Braun S, Appel L and Schmal M (2003). Pollution generated by internal combustion engine powered diesel- The question of particulate. Current strategies for the reduction and control of emissions and future trends. New Chemistry 27: $472-482$.

Cassoni F, Bocchi C, Martino A, Pinto G, et al. (2004). The Salmonella mutagenicity of urban airborne particulate matter (PM2.5) from eight sites of the Emilia-Romagna regional monitoring network (Italy). Sci. Total Environ. 324: 79-90.

CET-RIO (Companhia de Engenharia de Tráfego do Rio de Janeiro) (2011). Available at [http://www.rio.rj.gov.br/web/ cetrio]. Accessed December 4, 2011.

Cheng Y, Lee SC, Ho KF, Chow JC, et al. (2010). Chemically-speciated on-road PM(2.5) motor vehicle emission factors in Hong Kong. Sci. Total Environ. 408: 1621-1627.

Claxton LD and Woodall GM Jr (2007). A review of the mutagenicity and rodent carcinogenicity of ambient air. Mutat. Res. 636: 36-94. 
Collins JF, Brown JP, Dawson SV and Marty MA (1991). Risk assessment for benzo[a]pyrene. Regul. Toxicol. Pharmacol. 13: $170-184$.

Collins JF, Brown JP, Alexeeff GV and Salmon AG (1998). Potency equivalency factors for some polycyclic aromatic hydrocarbons and polycyclic aromatic hydrocarbon derivatives. Regul. Toxicol. Pharmacol. 28: 45-54.

Coronas MV, Pereira TS, Rocha JA, Lemos AT, et al. (2009). Genetic biomonitoring of an urban population exposed to mutagenic airborne pollutants. Environ. Int. 35: 1023-1029.

Dongarrá G, Manno E, Varrica D, Lombardo M, et al. (2010). Study on ambient concentrations of PM10, PM10-2.5, PM2.5 and gaseous pollutants. Trace elements and chemical speciation of atmospheric particulates. Atmos. Environ. 44: 5244-5257.

Environment Canada (1997). Environmental Assessments of Priority Substances Under the Canadian Environmental Protection Act, EPS/2/CC/3E. Chemical Evaluation Division, Commercial Chemicals Evaluation Branch, Environment Canada, Government of Canada, Ottawa.

Fahl WE, Scarpelli DG and Gill K (1981). Relationship between benzo(a)pyrene-induced DNA base modification and frequency of reverse mutations in mutant strains of Salmonella typhimurium. Cancer Res. 41: 3400-3406.

Fernandes MB, Brickus LS, Moreira JC and Cardoso JN (2002). Atmospheric BTX and polyaromatic hydrocarbons in Rio de Janeiro, Brazil. Chemosphere 47: 417-425.

Godoy MLDP, Godoy JM, Luiz Alfredo R, Soluri DS, et al. (2009). Coarse and fine aerosol source apportionment in Rio de Janeiro, Brazil. Atmos. Environ. 43: 2366-2374.

Ianistcki M, Dallarosa J, Sauer C, Teixeira CE, et al. (2009). Genotoxic effect of polycyclic aromatic hydrocarbons in the metropolitan area of Porto Alegre, Brazil, evaluated by Helix aspersa (Muller, 1774). Environ. Pollut. 157: 2037-2042.

IARC (International Agency for Research on Cancer) (2011). Agents Classified by the IARC Monographs. Volumes 1-102. Available at [http://monographs.iarc.fr/ENG/Classification/ClassificationsGroupOrder.pdf]. Accessed September 27, 2011.

INEA (Instituto Estadual do Ambiente) (2009). Relatório Anual da Qualidade do Ar do Estado do Rio de Janeiro. Available at [http://www.inea.rj.gov.br/downloads/relatorios/qualidade_ar_2009.pdf]. Accessed September 27, 2011.

Jornal do Brasil (2012). Túnel Rebouças parado; tempo de travessia é de $2 \mathrm{~h} 30$. Available at [http://www.jb.com.br/rio/ noticias/2010/03/06/tunel-reboucas-parado-tempo-de travessia-e-de-2h30/]. Accessed January 4, 2012.

Kado NY, Langley D and Eisenstadt E (1983). A simple modification of the Salmonella liquid-incubation assay. Increased sensitivity for detecting mutagens in human urine. Mutat. Res. 121: 25-32.

Kado NY, Guirguis GN, Flessel CP, Chan RC, et al. (1986). Mutagenicity of fine (less than 2.5 microns) airborne particles: diurnal variation in community air determined by a Salmonella micro preincubation (microsuspension) procedure. Environ. Mutagen. 8: 53-66.

Kavouras IG, Lawrence JL, Koutrakis P, Stephanou EG, et al. (1999). Measurement of particulate aliphatic and polynuclear aromatic hydrocarbons in Santiago de Chile: source reconciliation and evaluation of sampling artifacts. Atmos. Environ. 33: 4977-4986.

Kyrtopoulos SA, Georgiadis P, Autrup H, Demopoulos NA, et al. (2001). Biomarkers of genotoxicity of urban air pollution. Overview and descriptive data from a molecular epidemiology study on populations exposed to moderateto-low levels of polycyclic aromatic hydrocarbons: the AULIS project. Mutat. Res. 496: 207-228.

Laden F, Neas LM, Dockery DW and Schwartz J (2000). Association of fine particulate matter from different sources with daily mortality in six U.S. cities. Environ. Health Perspect. 108: 941-947.

Lewtas J, Walsh D, Williams R and Dobias L (1997). Air pollution exposure-DNA adduct dosimetry in humans and rodents: evidence for non-linearity at high doses. Mutat. Res. 378: 51-63.

Maron DM and Ames BN (1983). Revised method for Salmonella mutagenicity test. Mutat. Res. 113: 175-215.

Miguel AG, Daisey JM and Sousa JA (1990). Comparative study of the mutagenic and genotoxic activity associated with inhalable particulate matter in Rio de Janeiro air. Environ. Mol. Mutagen. 15: 36-43.

OEHHA (Office of Environmental Health Hazard Assessment) (1994). Part B. Health Assessment. In: Benzo[a]pyrene as a Toxic Air Contaminant. Air Resources Board and Office of Environmental Health Hazard Assessment. California Environmental Protection Agency (Cal/EPA), Sacramento.

Seguel AR, Morales SRIGE and Leiva GMA (2009). Estimations of primary and secondary organic carbon formation in PM2.5 aerosols of Santiago City, Chile. Atmos. Environ. 43: 2125-2131.

SISAET (Sistema de Informações do Anuário Estatístico dos Transportes). (2011). Capítulo 5 - Transporte Rodoviário Available at [http://www.geipot.gov.br/NovaWeb/IndexAnuario.htm]. Accessed August 28, 2011.

Topinka J, Binkova B, Mrackova G, Stavkova Z, et al. (1997). DNA adducts in human placenta as related to air pollution and to GSTM1 genotype. Mutat. Res. 390: 59-68.

Umbuzeiro GA, Franco A, Martins MH, Kummrow F, et al. (2008). Mutagenicity and DNA adduct formation of PAH, nitro-PAH, and oxy-PAH fractions of atmospheric particulate matter from Sao Paulo, Brazil. Mutat. Res. 652: 72-80.

Genetics and Molecular Research 12 (3): 3992-4002 (2013) 
USEPA (US Environmental Protection Agency) (1996). Proposed Guidelines for Carcinogen Risk Assessment, EPA/600/ P-92/003C. Office of Research and Development. U.S. Environmental Protection Agency, Washington.

Vargas VMF, Horn RC, Guidobono RR, Mittelstaed AB, et al. (1998). Mutagenic activity of airborne particulate matter from the urban area of Porto Alegre, Brazil. Gen. Mol. Biol. 21: 247-253.

Vinitketkumnuen U, Kalayanamitra K, Chewonarin T and Kamens R (2002). Particulate matter, PM10 \& PM2.5 levels, and airborne mutagenicity in Chiang Mai, Thailand. Mutat. Res. 519: 121-131.

WHO (World Health Organization) (2005). Air Quality Guidelines: Global Update 2005. Particulate Matter, Ozone, Nitrogen Dioxide and Sulfur Dioxide. WHO Regional Office for Europe, Copenhagen.

Zheng M and Fang M (2000). Particle-associated polycyclic aromatic hydrocarbons in the atmosphere of Hong Kong. Water Air Soil Pollution 117: 175-189. 